\title{
Silicon alters early development of bean seedlings from seeds infected by Anthracnose
}

Patrícia Migliorini, Cristina Rossetti, Andreia da Silva Almeida, Bruna Barreto Reis, Gustavo Fonseca Rodrigues, Lilian Vanussa Madruga de Tunes

Universidade Federal de Pelotas - UFPEL, RS. E-mail: cristinarosseti@yahoo.com.br

\begin{abstract}
The present study aimed to evaluate the effect of seed coating with $\mathrm{Si}$ in response to infection in a cultivar susceptible and resistant to Colletotrichum lindemuthianum, on the physiological and health potential of seeds and seedlings, during the initial development of bean culture. The experiment was carried out in a completely randomized design, in a $2 \times 2 \times 2$ factorial scheme, with four replications, where the factors were: cultivar (BRS Esplendor and IPR Tuiuiú), silicate application (with and without Agrosilício ${ }^{\circledR}$ coating) $^{2}$ and inoculation (seeds inoculated or not with C. lindemuthianum). In the evaluation of the initial development of the culture, the following variables were measured: germination, first count of the germination test, emergence, emergence speed index (IVE), total seedling length, shoot and root length, total dry mass, aerial part dry matter, root dry matter and aerial part dry matter at 15 days after sowing (DAS). The incidence of $\mathrm{C}$. lindemuthianum in beans was determined by the paper roll method. Covering the seeds with Si reduces the incidence and severity of $\mathrm{C}$. lindemuthianum and provides greater growth of bean seedlings. The effect of responses potentiated by $\mathrm{Si}$ is more expressive in the cultivar of greater susceptibility.
\end{abstract}

Keywords: germination; mineral nutrition; Phaseolus vulgaris L.; seed coating, Colletotrichum lindemuthianum.

\section{Silício altera desenvolvimento inicial de plântulas de feijão oriundas de sementes infectadas por Antracnose}

\section{Resumo}

O presente trabalho teve por objetivo, avaliar o efeito do recobrimento de sementes com Si em resposta à infecção em uma cultivar suscetível e resistente ao Colletotrichum lindemuthianum, sobre o potencial fisiológico e sanitário de sementes e plântulas, durante o desenvolvimento inicial da cultura do feijão. 0 experimento foi realizado em delineamento inteiramente casualizado, em esquema fatorial $2 \times 2 \times 2$, com quatro repetições, onde os fatores foram: cultivar (BRS Esplendor e a IPR Tuiuiú), aplicação de silicato (com e sem recobrimento com Agrosilício ${ }^{\circledR}$ ) e inoculação (sementes inoculadas ou não com C. lindemuthianum). $\mathrm{Na}$ avaliação do desenvolvimento inicial da cultura foram mensuradas as seguintes variáveis: germinação, primeira contagem do teste de germinação, emergência, índice da velocidade de emergência (IVE), comprimento total da plântula, comprimento de parte aérea e de raiz, massa seca total, massa seca de parte aérea, massa seca de raiz e massa seca de parte aérea aos 15 dias após semeadura (DAS). A incidência de $C$. lindemuthianum em feijão foi determinada pelo método do rolo de papel. O recobrimento das sementes com Si diminui a incidência e a severidade de $C$. lindemuthianum e proporciona maior crescimento das plântulas de feijão. $\mathrm{O}$ efeito de respostas potencializadas pelo $\mathrm{Si}$ tem maior expressividade na cultivar de maior suscetibilidade.

Palavras-chave: germinação; nutrição mineral; Phaseolus vulgaris L.; revestimento de sementes, Colletotrichum lindemuthianum. 


\section{Introduction}

Anthracnose caused by Colletotrichum lindemuthianum (Sacc \& Magnus) Lams. Scrib is the main fungal disease of bean crop. It is a devastating disease in regions with moderate temperature and high relative humidity causing up to $100 \%$ damage to grain yield in highly susceptible cultivars and compromising seed quality (PADDER et al., 2017).

Seeds contaminated by the fungus are the main form of survival and dissemination of $C$. lindemuthianum to undamaged areas, representing a great threat during the establishment of the crop. The pathogen can also survive in cultural remains. Secondary dissemination occurs mainly through water splashes and wind (SINGH; SCHWARTZ, 2010; SILVA et al,. 2013). The disease can occur at any stage of development, but it is during the seedling phase that the greatest susceptibility to the pathogen occurs, as the tissues are poorly lignified. Anthracnose lesions can occur in cotyledons, hypocotyl, leaves, stem, branches, pods and seeds (CAMPA et al., 2015).

The management of the disease must involve a set of measures such as crop rotation, use of resistant cultivars, pathogen-free seeds, and fungicides for the treatment of seeds and for spraying on the aerial part. However, the sequential use of fungicide can lead to the selection of individuals resistant to certain chemical groups (SINGH; SCHWARTZ, 2010; CRUZ et al., 2014; MARINGON, 2002l; TRABANCO et al., 2015). Thus, other strategies with the use of alternative measures are important to reduce the damage caused by the disease. Among the potential alternatives is silicon.

Silicon ( $\mathrm{Si}$ ) is considered a non-essential element, but it plays a significant role, especially in reducing biotic and abiotic damage to plants (DEBONA et al., 2017). In many cultures the effect of $\mathrm{Si}$ is reported to reduce disease intensity (DALLAGNOL et al., 2015; FORTUNATO et al., 2012, 2014; POLANCO et al.; DORNELES et al., 2017). The mechanisms by which $\mathrm{Si}$ acts, range from a physical barrier to the penetration of pathogens by deposition of $\mathrm{Si}$ and polymerization in the cuticle and cell wall (HUANG et al., 2011; GUERRIERO et al., 2016); as well as by activating plant defense biochemical responses by activating defense enzymes (POLANCO et al., 2014; DORNELES et al., 2017), production of phenolic compounds (TATAGIBA et al., 2014), phytoalexins (HAYNES, 2017) and lignin (POLANCO et al., 2012); and at the molecular level by regulating the expression of genes involved in the defense and response to stress (GHAREEB et al., 2011; WANG et al., 2015).

The high leaf concentration of Si reduced the symptoms of anthracnose in the ribs of bean leaves (CRUZ et al., 2014), increased the activities of antioxidant enzymes (POLANCO et al., 2014) and the concentration of lignin (POLANCO et al., 2012), important events for increasing the plant's resistance against fungus infection. Rice plants supplied with Si produced vigorous seeds with a lower incidence of symptoms of Bipolar oryzae in seedlings (DALLAGNOL et al., 2013). In tomato, the increase in the concentration of silicon in the root correlated positively with the reduction in the severity of the disease caused by Fusarium oxysporum f. sp. radicis-lycopersici (HUANG et al., 2011). Tunes et al. (2014), found that seed coating with CAC and kaolin reduced the incidence of fungi in rice seeds. The application of Si-containing products in the treatment of rice and soybean seeds has resulted in greater emergence and development of seedlings with greater vigor (TUNES et al., 2014; OLIVEIRA et al., 2016). Thus, it is believed that the covering of bean seeds with products containing $\mathrm{Si}$, can be potentially beneficial for the development of seedlings, in addition to strengthening the defense against the attack of pathogens in the early stages of the crop.

In this study, the effect of silicon seed coating in response to infection in a cultivar susceptible and resistant to $C$. lindemuthianum was evaluated on the physiological and health potential of seeds and seedlings during the initial development of beans.

\section{Material and Methods}

The experiment was carried out at the Seed Analysis Laboratory and at the Seed Pathology Laboratory of the Faculty of Agronomy Eliseu Maciel, of the Federal University of Pelotas, Campão do Leão - RS. The cultivars BRS Esplendor, characterized as resistant, and IPR Tuiuiú, characterized as susceptible to $C$. lindemuthianum (COSTA et al., 2011; IAPAR, 2010), were used in the experiments. The superficial disinfestation of the seeds was carried out through baths, of 60 seconds each, with $70 \%$ alcohol $(v / v)$, followed by sodium hypochlorite $1 \%(\mathrm{v} / \mathrm{v})$ and three baths of distilled and sterilized 
water (JUNGES et al., 2017). Then, the seeds were put to dry under filter paper at room temperature for 48 hours, and subsequently subjected to the inoculation process.

Inoculation in bean seeds: The isolate CL01 from C. lindemuthianum, belonging to the library of the Plant Bacteriology Laboratory of the Federal University of Pelotas was used for inoculation. To this end, the fungus was seeded in petri dishes containing BDA culture medium (potato, dextrose and agar) modified in order to restrict water to $-0.6 \mathrm{Mpa}$ using sucrose solute. Immediately after the fungus was harvested, the plates were incubated in a BOD-type growth chamber at $22 \pm 1$ - $\mathrm{C}$ and a 12 -hour photoperiod for 25 days (CARVALHO, 1999). After this period, the bean seeds were randomly distributed on the plates and lightly pressed on the medium completely colonized by the fungus, the treatment containing seeds not artificially inoculated with the fungus was conditioned only on the modified culture medium, for 48 hours, at a temperature of $22^{\circ} \mathrm{C}$ and a photoperiod of $12 \mathrm{~h}$. Then the seeds were removed and distributed on filter paper, at a controlled temperature of $20^{\circ} \mathrm{C}$, for 48 hours, so that they could return to the initial water content. After this period, the seeds were submitted to the Si coating process.

Silicon Application: The source of Si used was Agrosilício $^{\circledR}$ (calcium and magnesium silicate), composed of $10.5 \% \mathrm{Si}, 25 \%$ calcium and $7 \%$ magnesium. The form of application of $\mathrm{Si}$ was by covering the seeds, at a dose of $90 \mathrm{~g}$ of Si for $100 \mathrm{~kg}$ of seed (+ Si), equivalent to $854.7 \mathrm{~g}$ of the commercial product, plus polymer (Collor Seed ${ }^{\circledR}$ ) and water totaling a volume of syrup from $1 \mathrm{~L}$ to $100 \mathrm{~kg}^{-1}$ of seeds. The coating process was carried out manually in plastic polyethylene bags. For this, $90 \mathrm{~g}$ of $\mathrm{Si}, 300 \mathrm{~mL}$ of polymer and $700 \mathrm{~mL}$ of water were homogenized, and then $200 \mathrm{~g}$ of seeds were added, followed by manual agitation of the bags for 2 minutes, until the product was completely adhered to the seed. Then, the bags containing the covered seeds were opened and the seeds were placed to dry at $20{ }^{\circ} \mathrm{C}$ for 48 hours. In the treatment without silicate coating ($\mathrm{Si})$, the seeds only received $300 \mathrm{~mL}$ of polymer and $700 \mathrm{~mL}$ of water.

Initial performance of bean seedlings: In the evaluation of the initial culture development, the following variables were measured: germination, first count of the germination test, emergence, emergence speed index (IVE), total seedling length, shoot length and of root, total dry matter, dry matter of aerial part, dry matter of root and dry matter of aerial part at 15 days after sowing (DAS).

The germination evaluation was carried out with four replications of 50 seeds per treatment, sown in a germitest ${ }^{\circledR}$ paper roll, moistened with distilled water, in the proportion of 2.5 times the mass of the paper and stored in a germinator at $25 \pm 2{ }^{\circ} \mathrm{C}$. The count of normal seedlings was carried out at five and nine days after the installation of the test and the results are expressed in percentages (BRASIL, 2009).

The first germination count test was carried out in conjunction with the germination test, constituting the record of the percentage of normal seedlings verified on the fifth day after sowing, the results being expressed in percentages of normal seedlings (BRASIL, 2009).

The seedling emergence evaluation was carried out with 200 seeds per treatment, distributed in four replications of 50 seeds. Each repetition was composed of 10 plastic cups of $500 \mathrm{~mL}$, containing sand washed, sieved and styled in an autoclave twice (120ㄷ $\mathrm{C}$ and 1atm for an hour with a $24 \mathrm{~h}$ interval). Five seeds were sown in each cup at a depth of $2 \mathrm{~cm}$. The sand was moistened with water, obeying the field capacity of $60 \%$ of the retention and kept moist whenever necessary. The treatments were kept in a controlled environment with a temperature of $20 \pm 1$ o $C$ and a photoperiod of $12 \mathrm{~h}$. The evaluation was carried out daily up to 15 days after sowing (DAS), considering normal emerged seedlings as those that had the primary leaves expanded in the final emergency, with results expressed in percentages. The daily emergency assessment data was used to determine the IVE. For this, for each repetition, the formula of Maguire (1962) was applied:

$$
\text { IVE: }(E 1 \div N 1)+(E 2 \div N 2)+\ldots+(E n \div N n) \text {. }
$$

Where: IVE = emergency speed index; E1, E2, En: number of normal seedlings computed in the first, second and last count and N1, N2, Nn: number of days between sowing and the first, second and last count.

The determination of the length of the aerial part, of the root and the total length of the seedling was carried out in a similar way to the one used in the germination test, being evaluated on the fifth day after the test assembly, in four subsamples of 10 seedlings for each treatment. The seedlings were randomly sampled from the sowing of 20 seeds by repetition in the upper 
third of the germitest ${ }^{\circledR}$ paper sheet, moistened with distilled water with 2.5 times the mass of the paper. The rolls were placed in a germinator at $25 \pm 2$ o $\mathrm{C}$. Measurements were determined with the aid of a ruler graduated in millimeters, the root length being obtained by subtracting the total length by the length of the aerial part. The results were expressed in centimeters (NAKAGAWA, 1999).

The determination of aerial part dry mass, root dry mass and total dry mass was carried out in the normal seedlings evaluated in the length test. The root and the aerial part of the seedlings of each repetition were separated and dried in an oven at $70^{\circ} \mathrm{C}$, until the constant weight, obtained in $72 \mathrm{~h}$. The total dry mass was obtained by adding the weight of the dry mass of root and dry mass of the aerial part, the results being expressed in grams (NAKAGAWA, 1999).

Dry mass of aerial part at 15 DAS was determined after the final count of the emergency test, aerial part of the normal seedlings of each repetition of the treatments were collected, placed in paper bags and dried in a regulated oven at $60^{\circ} \mathrm{C}$ until reaching constant weight, obtained in $72 \mathrm{~h}$. The results were expressed in grams per seedling.

Evaluation of the incidence and severity of $C$. lindemuthianum in beans: The incidence of C. lindemuthianum in beans was determined by the paper roll method, using four repetitions of 50 seeds (BRASIL, 2009). The seeds were distributed on sheets of germitest ${ }^{\circledR}$ paper, moistened with distilled water in the proportion of 2.5 times the mass of the paper. The rolls were packed in black plastic bags with small perforations, where they were then placed inside a BOD-type camera, with a controlled temperature of $22^{\circ} \mathrm{C}$ in the dark and remaining for a period of 7 days. The evaluation was performed on the seventh day after incubation, by observing dark necrotic lesions in the cotyledons and the hypocotyl. The results are expressed as a percentage of incidence.

In the plants of the emergency test, from the fifth day after sowing, evaluations of the symptoms of the disease in the primary leaves of the seedlings began. The evaluations were carried out every 48 hours using a diagrammatic scale described in Appendix B, by Dalla Pria and Amorim (2010). With the data of severity as a function of time, the area under the disease progress curve was calculated (CAMPBELL; MADDEN, 1990), according to the following formula: AACPD: $\Sigma\left[(Y 1+Y 2 / 2) *\left(t_{2}-t_{1}\right)\right]$. Where: $Y 1$ : evaluation score at time $t 1 ; \mathrm{Y} 2$ : grade of consecutive evaluation at time $\mathrm{t} 2$; $\mathrm{t} 1$-t2: interval in days between two consecutive evaluations.

The severity of the disease assessed at 15 DAS was determined by McKinney's disease index (MCKINNEY, 1923), according to the formula: ID (\%): $((\Sigma(Y * X y)) /(X t * h) * 100$. Where: Y: note; $X y$ : number of plants with this grade; $X t$ : total number of plants; h: maximum scale value.

Subsequently, at the end of the emergency test, the incidence of disease damage in the hypocotyl and leaf was determined. In this evaluation, damage characteristic of the disease was observed in all seedlings of the repetitions of treatments, the results being expressed as a percentage of disease incidence (MAFFIA et al., 2007).

Quantification of Phaseolin: To quantify phaseolin in bean hypocotyls, the methodology proposed by Dixon et al. (1983) with modifications. For that, the bean seeds were distributed evenly, in four repetitions of 10 seeds per treatment, in a germitest ${ }^{\circledast}$ paper roll and moistened with distilled water in the proportion of 2.5 times the mass of the paper. The paper rolls were placed in plastic bags with small perforations and deposited upright in a BOD camera at $25{ }^{\circ} \mathrm{C}$, in the dark. After seven days, four $4 \mathrm{~cm}$ segments from the central hypocotyl region were detached from the seedlings and weighed on a precision scale $(0.001 \mathrm{~g})$, after being transferred to test tubes, containing $10 \mathrm{~mL}$ of $98 \%$ ethanol. The test tubes were kept at $4{ }^{\circ} \mathrm{C}$ for $48 \mathrm{~h}$, and then shaken on a shaking table at 150rpm at 25 $\mathrm{C}$ for one hour, to extract the phaseolin. The concentration of the phaseolin formed was measured in a spectrophotometer at $280 \mathrm{~nm}$. The results were expressed in units of absorbance per gram per fresh mass.

Determination of the silicon and calcium concentration in the aerial part of the seedling: At the end of the experiment, the aerial part of seedlings (hypocotyl + leaf) from each repetition of the treatments was collected, washed with deionized water, dried at $70^{\circ} \mathrm{C}$ for $72 \mathrm{~h}$, then crushed in a mill with a 40 mesh sieve. The $\mathrm{Si}$ concentration was determined based on the colorimetric analysis of alkaline digestion of $0.1 \mathrm{~g}$ of dry tissue (ELLIOTT; SNYDER, 1991). The Ca concentration in the aerial part was determined by nitro-perchloric digestion of $0.2 \mathrm{~g}$ of dry tissue according to the methodology of Malavolta et al. (1987). 
Statistical analysis: The experiment was carried out in a completely randomized design, in a $2 \times 2 \times 2$ factorial scheme, with four replications, where the factors were: cultivar (BRS Esplendor and IPR Tuiuiú), silicate application (with and without Agrosilício coating ${ }^{\circledR}$ ) and inoculation (seeds inoculated or not with $C$. lindemuthianum).

The data were submitted to the tests of normality of the residues by Shapiro-Wilk and homogeneity of the variances by Bartlett, and when meeting the assumptions, the analysis of variance and the comparison of means by the Tukey test was made, at the level of $5 \%$ of probability. The variables that did not meet the assumptions were transformed using the Box-Cox system, making it possible to adjust the data for the ANOVA.

\section{Results and Discussion}

In this study, the presence of $C$. lindemuthianum in bean seeds negatively influenced the performance of normal seedlings in the PCG test, germination, IVE and final emergence, in addition to obtaining a higher percentage of disease incidence in seedlings (HF), index of disease and incidence of leaf damage and hypocotyl.

Initial performance of bean seedlings: In the first count of the germination test (PCG), there was no significant interaction between the factors, only for inoculation and cultivar (Table 1). Inoculation of seeds with $C$. lindemuthianum reduced the percentage of normal seedlings by $11 \%$, compared to uninoculated seeds. Among the cultivars CV. IPR Tuiuiú obtained the lowest percentage of PCG in relation to BRS Esplendor.

Table 1. Percentage of normal seedlings from the first germination count test, from bean seeds of two cultivars, which were inoculated (I) or not inoculated (NI) with C. lindemuthianum.

\begin{tabular}{cc}
\hline Treatments & First germination test count (\%) \\
\hline Inoculação & $78 \mathrm{~b}$ \\
I & $89 \mathrm{a}$ \\
$\mathrm{NI}$ & \\
Grow crops & $94 \mathrm{a}$ \\
BRS Esplendor & $72 \mathrm{~b}$ \\
IPR Tuiuiú & \\
\hline
\end{tabular}

* Means followed by the same letter do not differ significantly by Tukey's test at 5\% probability.

Significant interaction between cultivar and inoculation (Table 2) and inoculation and cover (Table 4) occurred for germination. The presence of the fungus in the seeds reduced the germination of the seeds independent of the covering (Table 4), being in $13 \%$ for the cV. IPU
Tuiuiú and 6\% at BRS Esplendor (Table 2). The cv. BRS Esplendor presented the highest germination percentages in relation to $\mathrm{CV}$. IPU Tuiuiú, about $21 \%$ for inoculated seeds and $14 \%$ for noninoculated seeds (Table 2).

Table 2. Percentage of germination as a function of bean cultivars inoculated (I) or not (NI) with $C$. lindemuthianum.

\begin{tabular}{ccc}
\hline \multirow{3}{*}{ Inoculation } & \multicolumn{3}{c}{ Grow crops } \\
\cline { 2 - 4 } & \multicolumn{3}{c}{ IPR Tuiuiú } & Germination (\%) \\
\cline { 2 - 4 } & & \multicolumn{3}{c}{$93 \mathrm{Ab}$} \\
$\mathrm{I}$ & $72 \mathrm{Bb}$ & $99 \mathrm{Aa}$ \\
\hline
\end{tabular}

* Means followed by the same lowercase letter in the column and uppercase in the row do not differ significantly by Tukey's test at $5 \%$ probability.

The cv. BRS Esplendor was significantly more vigorous than the IPR Tuiuiú, verified by the emergency tests, dry mass of root (MSR) (Table 3 ), total length of seedlings (CTP), length of aerial part (CPA), length of root (CR), seedling dry mass at 15 DAS (MSP15) and emergence speed index (IVE). 
Table 3. Averages of seedling emergence and dry root weight (MSR) as a function of bean cultivars.

\begin{tabular}{lcc}
\hline Grow crops & Emergency (\%) & MSR (g seedling ${ }^{-1}$ ) \\
\hline BRS Esplendor & $87 \mathrm{a}$ & $0,16 \mathrm{a}$ \\
IPR Tuiuiú & $62 \mathrm{~b}$ & $0,13 \mathrm{~b}$ \\
\hline
\end{tabular}

* Means followed by the same letter in the column do not differ significantly by Tukey's test at $5 \%$ probability.

Seedling emergence was negatively influenced in the presence of the fungus, regardless of seed covering and when comparing inoculated seeds within the covering, we found that when in the presence of the fungus, the seeds covered with $\mathrm{Si}$, provided an increase of $7 \%$ of normal seedlings emerged when compared to the absence of Si (Table 4).

Table 4. Seedling germination and emergence, depending on the covering (+ Si) or not (-Si) of the seeds with $\mathrm{Si}$ and the inoculation (I) or not (NI) with C. lindemuthianum.

\begin{tabular}{|c|c|c|c|c|}
\hline \multirow{3}{*}{$\begin{array}{c}\mathrm{Si} \\
\left(90 \mathrm{~g} 100 \mathrm{~kg}^{-1} \text { of seeds }\right)\end{array}$} & \multicolumn{4}{|c|}{ Inoculation } \\
\hline & 1 & $\mathrm{NI}$ & I & $\mathrm{NI}$ \\
\hline & \multicolumn{2}{|c|}{ Germination (\%) } & \multicolumn{2}{|c|}{ Emergency (\%) } \\
\hline$+\mathrm{Si}$ & $80 \mathrm{Ba}$ & $93 \mathrm{Aa}$ & $70 \mathrm{Ba}$ & $82 \mathrm{Aa}$ \\
\hline$-S \mathrm{i}$ & $84 \mathrm{Ba}$ & $91 \mathrm{Aa}$ & $65 \mathrm{Bb}$ & $81 \mathrm{Aa}$ \\
\hline
\end{tabular}

* Means followed by the same letter, lower case in the column and upper case in the line do not differ significantly by the Tukey test at $5 \%$ probability.

The dry root mass (MSR) was 35.3\% higher in seedlings from seeds covered with $\mathrm{Si}$, compared to those not covered. However, the opposite result was observed for dry mass of aerial parts, in the absence of $\mathrm{Si}$ there was an increase of $13.5 \%$ in the content of MSPA, in relation to those covered with Si (Table 5).

Table 5. Root dry matter (MSR) and aerial part dry matter (MSPA) of seedlings from seed covered (+ Si) or not with Si (-Si).

\begin{tabular}{ccc}
\hline Si & MSR & MSPA \\
$\left(90{\mathrm{~g} 100 \mathrm{~kg}^{-1} \text { of seeds) }}^{+}\right.$ & $---------\left(\right.$g seedling $\left.^{-1}\right)$ & $1,15 \mathrm{~b}$ \\
$-\mathrm{Si}$ & $0,17 \mathrm{a}$ & $1,33 \mathrm{a}$ \\
\hline
\end{tabular}

* Means followed by the same letter in the column do not differ significantly by Tukey's test at $5 \%$ probability.

Significant interaction between the factors cultivar, inoculation and seed covering, were verified for the tests of total seedling length (CTP), shoot length (CPA), root length (CR), seedling dry mass at 15 DAS (MSP15) and emergency speed index (IVE) (Table 6). Different behavior between cultivars in relation to the inoculated seeds was observed when the seeds were covered with $\mathrm{Si}$. The CV. IPR Tuiuiú (susceptible) inoculated, showed higher values of
CTP, CR and MSP15 in relation to those not inoculated, corresponding to an increase of approximately $15,19,13 \%$ respectively. As for the cv. BRS Esplendor (resistant), there was a reduction of CPA in $8.4 \%$ when in the presence of the fungus compared to the non-inoculated ones, while for the other variables (CTP, CR and MSP15) there were no significant differences (Table 6). 
Table 6. Total seedling length (CTP), shoot length (CPA), root length (CR), seedling dry mass at 15 DAS and emergence speed index (IVE), depending on the seed coverage with $\mathrm{Si}(+\mathrm{Si})$ or not (-Si) and inoculation (i) or not (NI) with C. lindemuthianum in two bean cultivars.

\begin{tabular}{|c|c|c|c|c|}
\hline \multirow{3}{*}{ Inoculation } & \multicolumn{4}{|c|}{ Total seedling length $\left(\mathrm{cm}^{2}\right.$ seedling $\left.{ }^{-1}\right)$} \\
\hline & \multicolumn{2}{|c|}{$+\mathrm{Si}$} & \multicolumn{2}{|c|}{$-\mathrm{Si}$} \\
\hline & IPR Tuiuiú & BRS Esplendor & IPR Tuiuiú & BRS Esplendor \\
\hline 1 & $22.95 \mathrm{Ba} \alpha$ & $27.32 \mathrm{Aa} \alpha$ & $14.02 \mathrm{Ba} \beta$ & $20.54 \mathrm{Aa} \beta$ \\
\hline \multirow[t]{2}{*}{$\mathrm{NI}$} & $19.60 \mathrm{Bb} \alpha$ & 28.92 Aa $\alpha$ & $13.53 \mathrm{Ba} \beta$ & $19.39 \mathrm{Aa \beta}$ \\
\hline & \multicolumn{4}{|c|}{ Shoot length $\left(\mathrm{cm}\right.$ seedling ${ }^{-1}$ ) } \\
\hline \multirow[t]{2}{*}{ Inoculation } & \multicolumn{2}{|c|}{$+\mathrm{Si}$} & \multicolumn{2}{|c|}{$-\mathrm{Si}$} \\
\hline & IPR Tuiuiú & BRS Esplendor & IPR Tuiuiú & BRS Esplendor \\
\hline 1 & $10.20 \mathrm{Ba} \alpha$ & $12.59 \mathrm{Ab} \alpha$ & $6.05 \mathrm{Ba} \beta$ & $7.79 \mathrm{Aa} \beta$ \\
\hline \multirow[t]{2}{*}{$\mathrm{NI}$} & $9.25 \mathrm{Ba} \alpha$ & 13.75 Aa $\alpha$ & $5.81 \mathrm{Ba} \beta$ & $7.31 \mathrm{Aa} \beta$ \\
\hline & \multicolumn{4}{|c|}{ Root Length (cm Seedling ${ }^{-1}$ ) } \\
\hline \multirow[t]{2}{*}{ Inoculation } & \multicolumn{2}{|c|}{$+\mathrm{Si}$} & \multicolumn{2}{|c|}{$-\mathrm{Si}$} \\
\hline & IPR Tuiuiú & BRS Esplendor & IPR Tuiuiú & BRS Esplendor \\
\hline 1 & $12.75 \mathrm{Ba \alpha}$ & 14.73 Aa $\alpha$ & $7.97 \mathrm{Ba} \beta$ & $12.76 \mathrm{Aa \beta}$ \\
\hline \multirow[t]{2}{*}{$\mathrm{NI}$} & $10.35 \mathrm{Bb} \alpha$ & 15.17 Aa $\alpha$ & $7.72 \mathrm{Ba} \beta$ & $12.08 \mathrm{Aa} \beta$ \\
\hline & \multicolumn{4}{|c|}{ Seedling dry mass at 15 DAS (g seedling ${ }^{-1}$ ) } \\
\hline \multirow[t]{2}{*}{ Inoculation } & \multicolumn{2}{|c|}{$+\mathrm{Si}$} & \multicolumn{2}{|c|}{$-\mathrm{Si}$} \\
\hline & IPR Tuiuiú & BRS Esplendor & IPR Tuiuiú & BRS Esplendor \\
\hline I & $0.08 \mathrm{Ba} \alpha$ & $0.10 \mathrm{Aa} \alpha$ & $0.06 \mathrm{Bb} \beta$ & 0.01 Aa $\alpha$ \\
\hline \multirow[t]{2}{*}{$\mathrm{NI}$} & $0.07 \mathrm{Bb} \alpha$ & 0.11 Aa $\alpha$ & $0.07 \mathrm{Ba \alpha}$ & 0.11 Aa $\alpha$ \\
\hline & \multicolumn{4}{|c|}{ IVE } \\
\hline \multirow[t]{2}{*}{ Inoculation } & \multicolumn{2}{|c|}{$+\mathrm{Si}$} & \multicolumn{2}{|c|}{$-\mathrm{Si}$} \\
\hline & IPR Tuiuiú & BRS Esplendor & IPR Tuiuiú & BRS Esplendor \\
\hline 1 & $1.63 \mathrm{Bb} \alpha$ & $2.13 \mathrm{Ab \alpha}$ & $1.44 \mathrm{Ab} \beta$ & $1.52 \mathrm{Ab} \beta$ \\
\hline $\mathrm{NI}$ & $1.98 \mathrm{Ba} \alpha$ & 3.53 Aa $\alpha$ & $1.98 \mathrm{Ba} \alpha$ & $2.62 \mathrm{Aa} \beta$ \\
\hline
\end{tabular}

* Means followed by the same lowercase letter in the column and uppercase in the row do not differ significantly from each other by the Tukey test at $5 \%$ probability. Means followed by equal symbols $(\beta$ or $\alpha)$ do not differ significantly for silicon (with $+\mathrm{Si}$ and without $-\mathrm{Si}$ ) within each inoculated (I) or uninoculated (NI) cultivar.

When in the absence of $\mathrm{Si}$, there were no statistically significant differences for the growth variables (CTP, CPA, CR and MSP15) in relation to the inoculation within each cultivar, except for MSP15 which the fungus provided a reduction of $5.9 \%$, in compared to those not inoculated (Table $6)$.

Inoculated seeds $C$. lindemuthianum provided a reduction in IVE regardless of cultivar and seed covering, negatively affecting the rapid emergence of seedlings (Table 6).

Seeds covered with $\mathrm{Si}$, regardless of cultivar and inoculation, provided seedlings with higher CTP, CPA, CR and IVE, except in this last variable, where the supply of $\mathrm{Si}$ in $\mathrm{cv}$. IPU Tuiuiú not inoculated, had no significant effect. While for MSP15, the significant effect of Si was only observed for cv. IPU Tuiuiú inoculated with the fungus, which presented an increase of $17 \%$ in comparison with the uncovered seeds (Table 6).

Incidence and severity of anthracnose: A lower incidence of symptoms of $C$. lindemuthianum $(\mathrm{Cl})$ in cotyledons and in the hypocotyl of bean seedlings was observed in cv. BRS Esplendor when compared to cV. IPU Tuiuiú (Tables 7 and 8), and in uninoculated seeds, in relation to the inoculated seeds regardless of the cultivar (Table 7). In cv. IPU Tuiuiú, the seeds covered with Si showed an incidence of $17.25 \%$ lower in relation to the seeds not covered. However, there was no significant difference regarding the effect of Si for cv. BRS Esplendor (Table 7). 
Table 7. Incidence of $C$. lindemuthianum in beans $(\mathrm{Cl})$, depending on the seed coverage with $\mathrm{Si}(+\mathrm{Si})$ or not (-Si) and cultivars.

\begin{tabular}{ccc}
\hline $\mathrm{Si}$ & \multicolumn{2}{c}{ Incidence of $\boldsymbol{C}$. lindemuthianum (\%) } \\
\cline { 2 - 3 }$\left(90 \mathrm{~g} 100 \mathrm{~kg}^{-1}\right.$ of seeds $)$ & IPR Tuiuiú & BRS Esplendor \\
\hline$+\mathrm{Si}$ & $44,50 \mathrm{Ab}$ & $17,25 \mathrm{Ba}$ \\
$-\mathrm{Si}$ & $61,75 \mathrm{Aa}$ & $21,25 \mathrm{Ba}$ \\
\hline
\end{tabular}

* Means followed by the same lowercase letter in the column and uppercase in the row do not differ significantly by Tukey's test at $5 \%$ probability.

The area under the disease progress curve (AACPD) was $88 \%$ smaller in seedlings originating from uninoculated seeds, compared to those inoculated in cv. BRS Esplendor (Table 8).

Table 8. Incidence of $C$. lindemuthianum in beans $(\mathrm{CI})$, area under the disease progress curve (AACPD) and induction of phaseolin in hypocotyls, depending on cultivars and inoculation (I) or not (NI) of $C$. lindemuthianum in bean seeds.

\begin{tabular}{|c|c|c|c|c|c|c|}
\hline \multirow{3}{*}{ Inoculation } & \multicolumn{6}{|c|}{ Grow crops } \\
\hline & IPR & BRS & IPR & BRS & IPR & BRS \\
\hline & Tuiuiú & Esplendor & Tuiuiú & Esplendor & Tuiuiú & Esplendor \\
\hline & \multicolumn{2}{|c|}{ IC (\%) } & \multicolumn{2}{|c|}{ AACPD } & \multicolumn{2}{|c|}{ Phaseolin (ABS(280nm)/g.p.f) } \\
\hline I & $84 \mathrm{Aa}$ & $35 \mathrm{Ba}$ & $5,63 \mathrm{Aa}$ & 6,71 Aa & $0,81 \mathrm{Aa}$ & $0,60 \mathrm{Ba}$ \\
\hline $\mathrm{NI}$ & $22,3 \mathrm{Ab}$ & $3,5 \mathrm{Bb}$ & $5,21 \mathrm{Aa}$ & $0,81 \mathrm{Bb}$ & $0,52 \mathrm{Ab}$ & $0,58 \mathrm{Aa}$ \\
\hline
\end{tabular}

* Means followed by the same lowercase letter in the column and uppercase in the row do not differ significantly by Tukey's test at $5 \%$ probability.

There was no significant difference in AACPD between cultivars for inoculated seeds, but for seedlings of non-inoculated seeds, AACPD was $84.4 \%$ lower in $\mathrm{cv}$. BRS Esplendor in relation to IPR Tuiuiú (Table 8). Therefore, for AACPD it was $75 \%$ lower in seedlings from seeds covered with $\mathrm{Si}$ compared to seedlings of seeds not covered (Table 9).

Table 9. Area under the disease progress curve (AACPD) of seeds covered (+ Si) or not with $\mathrm{Si}(-\mathrm{Si})$.

\begin{tabular}{cc}
\hline $\mathrm{Si}\left(90 \mathrm{~g} 100 \mathrm{~kg}^{-1}\right.$ of seeds) & AACPD \\
\hline$+\mathrm{Si}$ & $2,07 \mathrm{~b}$ \\
$-\mathrm{Si}$ & $8,25 \mathrm{a}$ \\
\hline
\end{tabular}

* Means followed by the same letter in the column do not differ significantly by Tukey's test at $5 \%$ probability.

Significant interaction between inoculation and cultivar occurred for the accumulation of phaseolin in bean hypocotyl. The highest absorbance, up to $36 \%$, was observed for cv. IPR Tuiuiú inoculated, compared to the same non-inoculated cultivar, and with cV. BRS Esplendor (Table 8). The accumulation of phaseolin in bean hypocotyl showed a significant interaction between inoculation and the $\mathrm{Si}$ coating. Inoculated seeds that did not receive the $\mathrm{Si}$ coating, obtained greater absorbance, compared to the non-inoculated ones, and with the seedlings covered with $\mathrm{Si}$ (Table 10). 
Table 10. Induction of phaseolin in bean hypocotyls as a function of seed coating with $\mathrm{Si}(+\mathrm{Si})$ or not (-Si) and inoculation (i) or not (NI) with C. lindemuthianum.

\begin{tabular}{|c|c|c|}
\hline \multirow{3}{*}{$\begin{array}{c}\mathbf{S i} \\
\left(90 \mathrm{~g} \cdot 100 \mathrm{~kg}^{-1} \text { of seeds }\right)\end{array}$} & \multicolumn{2}{|c|}{ Inoculation } \\
\hline & I & $\mathrm{NI}$ \\
\hline & \multicolumn{2}{|c|}{ Phaseolin (ABS (280nm)/g.p.f) } \\
\hline$+\mathrm{Si}$ & $0,59 \mathrm{Ab}$ & $0,59 \mathrm{Aa}$ \\
\hline$-\mathrm{Si}$ & $0,82 \mathrm{Aa}$ & $0,52 \mathrm{Ba}$ \\
\hline
\end{tabular}

* Means followed by the same lowercase letter in the column and uppercase in the row do not differ significantly by Tukey's test at $5 \%$ probability.

The cV. IPR Tuiuiú, regardless of inoculation and cover, showed the highest percentages of the disease index (ID), leaflet incidence (IF) and symptoms in the hypocotyl (IH) compared to cV. BRS Esplendor, except for ID in covered and inoculated seeds, where the cultivars did not show significant differences (Table 11).

As for inoculation, the presence of the fungus in the seeds of cv. BRS Esplendor provided the highest percentages of ID, IF and IH in relation to the non-inoculated ones, regardless of the seed covering, while for cv. IPU Tuiuiú, this behavior of increased damage was verified only for seeds covered with $\mathrm{Si}$, in the variables of ID and IF (Table 11).

Table 11. Disease index (ID), incidence of disease damage in leaves (IF), incidence of disease damage in the hypocotyl $(\mathrm{IH})$ caused by inoculation $(\mathrm{I})$ or not $(\mathrm{NI})$ of $C$. lindemuthianum depending on the coverage of the seeds with $\mathrm{Si}(+\mathrm{Si})$ or not $(-\mathrm{Si})$ in two bean cultivars.

\begin{tabular}{|c|c|c|c|c|}
\hline \multirow{3}{*}{ Inoculation } & \multicolumn{4}{|c|}{ Disease index (ID) (\%) } \\
\hline & \multicolumn{2}{|c|}{$+\mathrm{Si}$} & \multicolumn{2}{|c|}{$-\mathrm{Si}$} \\
\hline & IPR Tuiuiú & BRS Esplendor & IPR Tuiuiú & BRS Esplendor \\
\hline 1 & 17,29 Aa $\alpha$ & 15,07 Aa $\alpha$ & $33,58 \mathrm{Aa} \beta$ & $22,44 \mathrm{Ba} \beta$ \\
\hline \multirow[t]{2}{*}{$\mathrm{NI}$} & $12,81 \mathrm{Ab} \alpha$ & $10,49 \mathrm{Bb} \alpha$ & $32,13 \mathrm{Aa} \beta$ & $10,87 \mathrm{Bb} \alpha$ \\
\hline & \multicolumn{4}{|c|}{ Incidence of disease damage in leaves (IF) (\%) } \\
\hline \multirow[t]{2}{*}{ Inoculation } & \multicolumn{2}{|c|}{$+\mathrm{Si}$} & \multicolumn{2}{|c|}{$-\mathrm{Si}$} \\
\hline & IPR Tuiuiú & BRS Esplendor & IPR Tuiuiú & BRS Esplendor \\
\hline 1 & 21,79 Аа $\alpha$ & $6,25 \mathrm{Ba \alpha}$ & $49,51 \mathrm{Aa} \beta$ & $33,59 \mathrm{Ba} \beta$ \\
\hline \multirow[t]{2}{*}{$\mathrm{NI}$} & 4,74 Aba & $0 \mathrm{Bb} \alpha$ & $52,42 \mathrm{Aa} \beta$ & $5,19 \mathrm{Bb} \beta$ \\
\hline & \multicolumn{4}{|c|}{ Incidence of disease damage in the hypocotyl (IH) (\%) } \\
\hline \multirow[t]{2}{*}{ Inoculation } & \multicolumn{2}{|c|}{$+\mathrm{Si}$} & \multicolumn{2}{|c|}{$-\mathrm{Si}$} \\
\hline & IPR Tuiuiú & BRS Esplendor & IPR Tuiuiú & BRS Esplendor \\
\hline 1 & 9,57 Aa $\alpha$ & $2,41 \mathrm{Ba \alpha}$ & 7,32 Aa $\alpha$ & $3,51 \mathrm{Ba \alpha}$ \\
\hline $\mathrm{NI}$ & $6,70 \mathrm{Aa} \alpha$ & $0,71 \mathrm{Bb} \alpha$ & 6,19 Aa $\alpha$ & $1,39 \mathrm{Bb} \alpha$ \\
\hline
\end{tabular}

* Means followed by the same lowercase letter in the column and uppercase in the row do not differ significantly by Tukey's test at $5 \%$ probability. Means followed by the same symbols ( $\beta$ or $\alpha)$ do not differ significantly from each other, for silicon (with $+\mathrm{Si}$ and without $-\mathrm{Si}$ ) within each inoculated (I) or uninoculated (NI) cultivar.

The covering of the seeds with $\mathrm{Si}$ significantly reduced the ID and IF, in comparison with the absence of $\mathrm{Si}$, regardless of the inoculation or cultivar, however this same difference was not observed between the covering of the seeds for the HI (Table 11).

Shoot concentration of silicon and calcium: There were no significant differences for the concentration of $\mathrm{Si}$ in aerial parts from seeds covered or not with Si. Significant interaction occurred between cultivar and inoculation. An increase of $18.8 \%$ in the $\mathrm{Si}$ concentration in the aerial part was observed for cV. BRS Splendor uninoculated compared to inoculated. Si concentration was $20.7 \%$ higher at BRS Esplendor compared to cV. IPU Tuiuiú, both not inoculated (Table 12). 
Table 12. Concentration of silicon (Si) in the aerial part of seedlings, depending on cultivars and inoculation (I) or not (NI) with C. lindemuthianum in bean seeds.

\begin{tabular}{ccc}
\hline \multirow{2}{*}{ Inoculation } & \multicolumn{2}{c}{ Si $\left(\mathrm{g} \mathrm{kg}^{-1}\right)$} \\
\cline { 2 - 3 } & IPR Tuiuiú & BRS Esplendor \\
\hline $\mathrm{NI}$ & $3,82 \mathrm{Aa}$ & $3,53 \mathrm{Ab}$ \\
$\mathrm{NI}$ & $3,45 \mathrm{Ba}$ & $4,35 \mathrm{Aa}$ \\
\hline
\end{tabular}

* Means followed by the same lowercase letter in the column and uppercase in the row do not differ significantly by Tukey's test at $5 \%$ probability.

For calcium concentration in the aerial part, there was a significant interaction between inoculation and Si coating (Table 13).

Table 13. Concentration of calcium (Ca) in the aerial part of seedlings, depending on the covering of the seeds with $\mathrm{Si}(+\mathrm{Si})$ or not (-Si) and of the inoculation (I) or not (NI) with C. lindemuthianum in seeds of bean.

\begin{tabular}{ccc}
\hline \multirow{2}{*}{ Inoculation } & \multicolumn{2}{c}{$\mathrm{Ca}\left(\mathrm{g} \cdot \mathrm{kg}^{-1}\right)$} \\
\cline { 2 - 3 } & $+\mathrm{Si}$ & $-\mathrm{Si}$ \\
\hline $\mathrm{NI}$ & $2,00 \mathrm{Bb}$ & $2,47 \mathrm{Aa}$ \\
& $2,49 \mathrm{Aa}$ & $2,41 \mathrm{Aa}$ \\
\hline
\end{tabular}

* Means followed by the same lowercase letter in the column and uppercase in the row do not differ significantly by Tukey's test at $5 \%$ probability.

In the inoculated seeds, the $\mathrm{Ca}$ concentration was $19 \%$ lower in seedlings from seeds covered with $\mathrm{Si}$ in relation to seedlings of seeds not covered. For seedlings from covered seeds, the Ca concentration was $19.7 \%$ higher in seedlings of uninoculated seeds compared to inoculated ones (Table 13).

The incidence of anthracnose symptoms in seedlings evaluated on a germitest paper roll $(\mathrm{Cl})$, varied from 35 to $84 \%$, while in leaves they reached $52.4 \%$ and in hypocotyl in $9.6 \%$ among cultivars, however note It is believed that the non-inoculated seeds also obtained high incidences of the disease in the seedlings, this fact is probably due to the fungus being infecting the seeds internally, since the superficial disinfestation of the seeds was carried out initially. Symptomatic seedlings showed small brown lesions in the cotyledons, and dark colored lesions in the hypocotyl, in an elongated and depressed shape. In the leaves, on the bottom, the dark brown necrotic lesions appeared on the ribs, while on the upper part, chlorotic lesions appeared next to the necrotic ones, and often causing deformation of the leaf. According to Silva et al. (2013), the greater the amount of inoculum in the seeds, under favorable environmental conditions for the development of the fungus, the greater the incidence and severity of the disease in the field. Rey et al. (2009), verified that the transmission of $C$. lindemuthianum seed-seedling can reach up to $80 \%$.

Among the cultivars, the best initial seedling performance was for cv. BRS Esplendor, which originated vigorous seedlings with high germination, a fact that may be related to a better initial seed quality. Lower incidence and severity of the disease was also observed in this cultivar, when compared to CV. IPR Tuiuiú. BRS Esplendor is considered a cultivar with a higher level of resistance among recent cultivars (PEREIRA et al., 2017).

In this work, covering the seeds with $\mathrm{Si}$ helped in the growth of bean seedlings, as well as in reducing the severity of anthracnose in the early stages of development. The reduction in the intensity of the disease was observed for both cultivars studied, IPR Tuiuiú (susceptible) and BRS Esplendor (resistant), indicating a possible potentiation of the resistance of the bean to $C$. lindemuthianum during the establishment of the seedlings.

Seeds of the susceptible cultivar (IPR Tuiuiú) inoculated with fungus and supplied with $\mathrm{Si}$ had a better response when compared to $\mathrm{cv}$. resistant, it was possible to observe a greater growth, in relation to the non-inoculated ones (Table 6). According to Cooke and Leishman (2016), Si has little effect on the metabolism of 
plants under normal conditions, but when exposed to some type of stress they can adapt efficiently, being beneficial in these conditions, as it has an important role in activities physiological or structural survival of plants. One of the probable ways in which Si provides resistance is through the induction of the priming state, which results in the anticipation and increase in the intensity of defense responses after infection (DALLAGNOL et al., 2015), such as the recruitment of defenses and in the absence of pathogens, metabolic costs are reduced (CONRATH et al., 2002).

The bean is a plant species that has the capacity to accumulate low concentrations of $\mathrm{Si}$ in the leaf tissues, reaching values of less than $5 \mathrm{~g}$ kg-1 in dry matter of the aerial part, which it classifies as a non-accumulating species of $\mathrm{Si}$, however these depend on the availability of $\mathrm{Si}$ in the medium, age of the plant, type and location of the tissues involved in the absorption, which directly affects the accumulated quantity (JONES; HANDRECH, 1987; DATNOFF et al., 2001). The highest concentration of $\mathrm{Si}$ in the aerial part of beans was observed in cv. BRS Splendor from uninoculated seeds, which may be related to greater production of dry matter, since the deposition and accumulation of $\mathrm{Si}$ is directly related to the production of biomass in bean seedlings (OLIVEIRA, 2009).

The deposition of the element can help in the rigidity of the plant, but it can also potentiate the host's defense enzymes and compounds (DALLAGNOL et al., 2015). The beneficial effects verified by the supply of $\mathrm{Si}$ in tomato seedlings, were involved in extracellular biochemical functions in the apoplast, even though no $\mathrm{Si}$ accumulation was found in the cells (SHI et al., 2014). According to Katz (2014), the beneficial effects of $\mathrm{Si}$ are not always proportional to its accumulation and the low concentration in the tissues does not mean that it has a limited function.

For the concentration of $\mathrm{Ca}$ in the aerial part of beans, a higher content was observed in seeds inoculated and without the covering with $\mathrm{Si}$, and in the seeds covered with $\mathrm{Si}$ and not inoculated. These results indicate that this element did not participate in the benefits generated by the covering of the seeds in the control of the disease, since effects occurred through the covering of the seeds are conferred by Si. Zambolim and Ventura (2012) report that the severity of the disease is inversely proportional to the content of $\mathrm{Ca}$ in plant tissue, however it was not possible to observe this relationship at work.

The supply of nutrients through the covering of seeds, provides benefits for the growth of seedlings, in addition to reducing the incidence and severity of the disease in the early stages of development in the bean culture. Regarding cultivar successive to $C$. lindemuthianum, Si contributed by mitigating the damage caused by the fungus, causing the seedlings to respond favorably to the supply of the element, through the technique of covering the seeds and thus being a promising measure in the system of integrated disease control management.

\section{Conclusions}

Covering the seeds with $\mathrm{Si}$ reduces the incidence and severity of Colletotrichum lindemuthianum and provides greater growth of bean seedlings.

The effect of responses potentiated by $\mathrm{Si}$ is more expressive in the cultivar of greater susceptibility.

\section{References}

BRASIL. Ministério da Agricultura, Pecuária e Abastecimento. Manual de análise sanitária de sementes. Brasília: Mapa/ACS, 2009. 200 p.

CAMPA, A.; RODRÍGUEZ-SUÁREZ, C.; GIRALDEZ, R.; FERREIRA, J.J. Genetic analysis of the response to eleven Colletotrichum lindemuthianum races in a RIL population of common bean (Phaseolus vulgaris L.). BMC Plant Biology, v.14, n.115, p.112, 2014. https://doi.org/10.1186/1471-2229-14$\underline{115}$

CARVALHO, J.C.B. Uso da Colletotrichum lindemuthianum em sementes de feijoeiro (Phaseolus vulgaris L.). 1999. 98 f. Dissertação (Mestrado em Fitopatologia) - Universidade Federal de Lavras, Lavras, 1999.

CONRATH, U.; PIETERSE, C.M.J.; MAUCH-MANI, B. Priming in plant-pathogen interactions. Trends Plant Science, v.7, p.210-216, 2002. https://doi.org/10.1016/S1360-1385(02)02244-6

COOKE, J.; LEISHMAN, M.R. Consistent alleviation of abiotic stress with silicon addition: a meta-analysis. Functional Ecology, v.30, p.1340- 
1357, 2016. https://doi.org/10.1111/1365$\underline{2435.12713}$

COSTA, J.G.C.; FARIA, L.C.; RAVA, C.A.; DEL PELOSO, M.J.; MELO, L.C.; DÍAZ, J.L.C.; FARIA, J.C.; SILVA, H.T.; SARTORATO, A.; BASSINELLO, P.Z.; ZIMMERMANN, F.J.P. BRS Esplendor common bean cultivar with black grain, upright growth and disease resistance. Crop Breeding And Applied Biotechnology, v.11, n.3, p.276-279, 2011. https://doi.org/10.1590/S198470332011000300011

CRUZ, M.F.A.; ARAUJO, L.; POLANCO, L.R.; RODRIGUES, F.A. Aspectos microscópicos da interação feijoeiro-Colletotrichum lindemuthianum mediados pelo silício. Bragantia, v.73, n.3, p.284-291, 2014. https://doi.org/10.1590/1678-4499.0139

DALLAGNOL, L. J.; RODRIGUES, F. A.; PASCHOLATI, S.F.; FORTUNATO, A.A.; CAMARGO, L.E.A. Comparison of root versus foliar applied potassium silicate in potentiating postinfection defences of melon against powdery mildew. Plant Pathology, v.64, n.5, p.1085-1093, 2015. https://doi.org/10.1111/ppa.12346

DALLAGNOL, L. J.; RODRIGUES, F.A.; MIELLI, M.V.B. Silicon improves the emergence and sanity of rice seedlings obtained from seeds infected with Bipolaris oryzae. Tropical plant pathology, v.38, n.6, p.478-484, 2013.

DIXON, R.A.; DEY, P.M.; LAWTON, M.A.; LAMB, C.J. Phytoalexin indution in french bean: intercellular transmission of elicitation in cell suspension cultures and hypocotyl sections Phaseolus vulgaris. Plant Physiology, v.71, n.2, p.251-256, 1983. https://doi.org/10.1104/pp.71.2.251

DORNELES, K.R.; DALLAGNOL, L.J.; PAZDIORA, P.C.; RODRIGUES, F.A.; DEUNER, S. Silicon potentiates biochemical defense responses of wheat against tan spot. Physiological and Molecular Plant Pathology, v.97, p.69-78, 2017. https://doi.org/10.1016/i.pmpp.2017.01.001

ELLIOTT, C.L.; SNYDER, G.H. Autoclave - induced digestion for the colorimetric determination of silicon in rice straw. Journal of Agricultural and
Food Chemistry, v.39, n.6, p.1118-1119, 1991. https://doi.org/10.1021/if00006a024

GHAREEB, H.; BOZSÓ, Z.; OTT, P.G.; REPENNING, C.; STAHL, F.; WYDRA, K. Transcriptome of siliconinduced resistance against Ralstonia solanacearum in the silicon non-accumulator tomato implicates priming effect. Physiological and Molecular Plant Pathology, v.75, p.83-89, 2011.

https://doi.org/10.1016/j.pmpp.2010.11.004

GUERRIERO, G.; HAUSMAN, J.F.; LEGAY, S. Silicon and the plant extracellular matrix. Frontiers in Plant Science, v.7, p.1-7, 2016. https://doi.org/10.3389/fpls.2016.00463

HAYNES, R.J. Chapter Three-Significance and Role of $\mathrm{Si}$ in Crop Production. Advances in Agronomy, v.146, p.83-166, 2017. https://doi.org/10.1016/bs.agron.2017.06.001

HUANG, C.H.; ROBERTS, P.D.; DATNOFF, L.E. Silicon suppresses Fusarium crown and root rot of tomato. Journal of Phytopathology, v.159, p. 546-554. 2011. https://doi.org/10.1111/j.1439$\underline{0434.2011 .01803 . x}$

IAPAR. Principais características das cultivares de feijão com sementes. 2010. Disponível em: http://www.iapar.br/modules/conteudo/conteud o.php?conteudo=1.

KATZ, O. Beyond grasses: the potential benefits of studying silicon accumulation in non-grass species. Frontiers in Plant Science, v.5, 2014. https://doi.org/10.3389/fpls.2014.00376

MALAVOLTA, E.; VITTI, G.C.; de OLIVEIRA, S.A. Avaliação do estado nutricional das plantas: princípios e aplicações. 2.ed. Piracicaba: POTAFOS. 1987. 319p.

MARINGONI, A.C.E; BARROS, M. Occurrence of Colletotrichum lindemuthianum isolates resistant to benzimidazole fungicides. Summa Phytopathologica, v.28, n.2, p.197-200, 2002.

NAKAGAWA, J. Testes de vigor baseados no desempenho das plântulas. In: KRZYZANOWSKI, F. C.; VIEIRA, R. D.; FRANÇA NETO, J. B. Vigor de sementes: conceitos e testes. Londrina: ABRATES, 1999. p. 2-21. 
OLIVEIRA, S.; BRUNES, A.P.; LEMES, E.S.; TAVARES, L.C.; MENEGHELLO, G.E.; LEITZKE, I.D.; MENDONÇA, A.O. Tratamento de sementes de arroz com silício e qualidade fisiológica das sementes. Revista de Ciências Agrárias, v.39, n.2, p.202-209, 2016. https://doi.org/10.19084/RCA15083

OLIVEIRA, Lilian Aparecida. Silicon in bean and rice plants: absorption, transport, redistribution and tolerance to cadmium. 2009. $157 \mathrm{f}$. Thesis (Doctorate) - University of São Paulo, Center for Nuclear Energy in Agriculture, Piracicaba, 2009. Available at: http://www.tese.usp.br/tese/disponiveis/64/641 34/tde-03122009-094223 /pt-br.php Accessed on: 15 jan. 2018.

POLANCO, L.R.; RODRIGUES, F.A.; NASCIMENTO, K.J.T.; SHULMAN, P.; SILVA, L.C.; NEVES, F.W.; VALE, F.X.R. Biochemical aspects of bean resistance to anthracnose mediated by silicon. Annals of Applied Biology, v.161, p.140-150, 2012.

POLANCO, L.R.; RODRIGUES, F.A.; NASCIMENTO, K.J.T.; CRUZ, M.F.A.; CURVELO, C.R.S.; DAMATTA, F.M.; VALE, F.X.R. Photosynthetic gas exchange and antioxidative system in common bean plants infected by Colletotrichum lindemuthianum and supplied with silicon. Tropical Plant Pathology, v.39, n.1, p.3542, 2014. https://doi.or $\mathrm{g} / 10.1590 / \mathrm{S} 1982-56762014000100005$

PADDER, B.A.; SHARMA, P.N.; AWALE, H.E.; KELLY, J.D. Colletotrichum lindemuthianum, the causal agent of bean anthracnose. Journal of Plant Pathology, v.99, n.2, p.317-330, 2017.

REY, M.S.; LIMA, N.B.; SANTOS, J.D; PIEROBOM, C.R. Transmissão semente-plântula de Colletotrichum Lindemuthinum em feijão (Phaseolus vulgaris). Arquivos do Instituto Biológico, v.76, n.3, p.465-470, 2009.

SILVA, M.G.; POZZA, E.A.; MACHADO, J.C. Influence of contaminated crop remains and seed health quality on the intensity of bean anthracnose. Journal of Agricultural Science, v.5, n.10, p.56-66, 2013. https://doi.org/10.5539/jas.v5n10p56
SINGH, S.P.; SCHWARTZ, H.F. Breeding common bean for resistance to diseases: a review. Crop Science, v.50, p.2199-2223, 2010. https://doi.org/10.2135/cropsci2009.03.0163

TATAGIBA, S.D.; RODRIGUES, F.A.; FILIPPI, M.C.C.; SILVA, G.B.; SILVA, L.C. Physiological responses of rice plants supplied with silicon to Monographella Ibescens infection. Journal of Phytopathol, v.162, p.596-606, 2014. https://doi.org/10.1111/iph.12231

TRABANCO, N.; CAMPA, A.; FERREIRA, J.J. Identification of a new chromosomal region involved in the genetic control of resistance to anthracnose in common bean. The Plant Genome, v.8, n.2, p.1-11, 2015. https://doi.org/10.3835/plantgenome2014.10.00 $\underline{79}$

TUNES, L.V.M.; FONSECA, D.A.R.; MENEGHELLO, G.E.; REIS, B.B.; BRASIL, V.D.; RUFINO, C.A.; VILLELA, F.A. Qualidade fisiológica, sanitária e enzimática de sementes de arroz irrigado recobertas com silício. Revista Ceres, v.61, n.5, p.675-685, 2014. https://doi.org/10.1590/0034$\underline{737 \times 201461050011}$

WANG, S.; LIU, P.; CHEN, D.; YIN, L.; LI, H.; DENG, $X$. Silicon enhanced salt tolerance by improving the root water uptake and decreasing the ion toxicity in cucumber. Frontiers in Plant Science, n.6, n.759, p.1-10, 2015. https://doi.org/10.3389/fpls.2015.00759

ZAMBOLIM, L.; VENTURA, J, A. Mecanismos de ação do cálcio na interação com doenças de plantas. In: ZAMBOLIM, L.; VENTURA, J. A.; JÚNIOR, L.A.Z. Efeito da nutrição mineral no controle de doenças de plantas. Viçosa: Independente, 2012. 321p. 